\title{
LOSS OF NUTRIENTS IN A HIGH YIELDING COCONUT PLANTATION THROUGH REMOVAL OF PLANT MATERIALS FROM THE FIELD
}

\author{
L. L.W. Somasiri, D. M. D. I. Wijebandara, B. D. P. Panditharatna, \\ S. Sabaratnam and C.P.A. Kurundukumbura
}

Coconut Research Institute, Lunuwila, Sri Lanka

\begin{abstract}
High yielding coconut palms absorb large quantities of nutrients from the soil. A high proportion of these nutrients are removed from the field along with the harvest and other plant components. The objective of this study was to determine the rate of macro and micro nutrient removal from the field by Typica $\times$ Typica coconut palms, yielding an average of 17,380 nuts per ha. per year, in order to assess the adequacy of the current fertilizer recommendations, to prevent a serious depletion of the nutrient reserves in the soil.
\end{abstract}

Harvested nuts, fallen fronds and inflorescence parts were collected for a two-year period from September 1998 to August 2000 from 10 palms located in a "Madampe series" soil at Bandirippuwa Estate. Their nutrient content was determined by chemical analysis of samples collected from harvested nuts, fallen fronds and fallen inflorescence parts. The reserves of plant nutrients in the soil were determined by chemical analysis of representative soil samples taken from the manure circle and the centre of squares at $0-15 \mathrm{~cm}$ and $15-100 \mathrm{~cm}$ depths.

The amounts of macronutrients lost through the removal of plant components from the site were $116.79 \mathrm{~kg} \mathrm{~N}, 14.02 \mathrm{~kg} \mathrm{P}, 245.43 \mathrm{~kg} \mathrm{~K}$, $40.47 \mathrm{~kg} \mathrm{Ca}$, and $33.66 \mathrm{~kg} \mathrm{Mg}$ per ha. per year. In addition, removal of $\mathrm{Na}$ was also observed at the rate of $55.79 \mathrm{~kg} / \mathrm{ha}$. Inputs at the recommended rate $(4.5 \mathrm{~kg}$ of Adult Palm Mixture (APM) and $1.5 \mathrm{~kg}$ of dolomite per palm per year) supplied $87.21 \mathrm{~kg} \mathrm{~N}, 17.07 \mathrm{~kg} \mathrm{P}, 188.90 \mathrm{~kg} \mathrm{~K}, 104.80 \mathrm{~kg} \mathrm{Ca}$ and $28.59 \mathrm{~kg} \mathrm{Mg}$ per ha per year (no sodium containing fertilizers were used). The difference between the removal and input should be supplied from reserves of nutrients in the soil. The study showed that except for exchangeable potassium ( $363 \mathrm{~kg} / \mathrm{ha})$, the other macronutrients were present in reasonably high quantities in the experimental site. As the potassium reserves in the soil are low and fertilizer inputs supply only about $77 \%$ of the requirement of high yielding coconut $(17,380$ nuts per ha. per year), soil potassium will deplete rapidly at the current production level. Hence, the depletion should be compensated for either by increasing the 
quantity of chemical fertilizer or recycling organic products of the palm itself or both.

The amounts of micronutrients lost were $1.14 \mathrm{~kg} \mathrm{Fe}, 0.63 \mathrm{~kg} \mathrm{Mn}, 0.13 \mathrm{~kg}$ $\mathrm{Cu}, 0.44 \mathrm{~kg} \mathrm{Zn}$ and $0.26 \mathrm{~kg} \mathrm{~B}$ per ha. per year. The soil reserve of available iron in the site was so high that a significant depletion of Fe would take more than 300 years. However $\mathrm{Mn}, \mathrm{Cu}$ and $\mathrm{Zn}$ depletion may need attention since reserves in the soil were not very high compared to the rate of removal.

\section{INTRODUCTION}

In coconut plantations, harvested nuts, as well as fronds and much of the other residues that fall from the palm are removed from the land for various purposes. This practice leads to gradual depletion of plant nutrients from the soil. Furthermore, the nutrients stored in the trunk are not returned to the soil. Application of fertilizers containing $\mathrm{N}, \mathrm{P}, \mathrm{K}$ and $\mathrm{Mg}$ at the recommended rates only partially compensates for this depletion. Previous studies indicate that nuts remove a considerable quantity of major nutrients (Jeganathan et al., 1977, Ohler, 1984, Jayasekara et al., 1991). The current general fertilizer recommendation of $800 \mathrm{~g}$ of urea, $600 \mathrm{~g}$ of rock phosphate, $1600 \mathrm{~g}$ of muriate of potash (Adult Palm Mixture) with $1 \mathrm{~kg}$ of dolomite per paim per year is aimed at meeting the demand of nutrients by plantations yielding 7500 nuts/ha/yr. The recommendation for high yielding plantations is 1.5 times the above rates (Mahindapala and Pinto, 1991). It would be sufficient for plantations yielding up to 11,250 nuts/ha/yr. Nevertheless, plantations yielding12,500-19,000 nuts/ha/yr, shown by land suitability studies (Somasiri et al., 1994) removes higher quantities of nutrients than the above inputs (Somasiri et al:, 2000., Somasiri, et al., 2001 ).

Information on the rate and amount of nutrient depletion from coconut lands of different yield potentials will be an uséful input to developing more logistic approaches to coconut nutrition and soil management. The objective of this study was to determine the rate of macro and micro nutrient removal from the field by Typica $x$ Typica coconut palms, yielding an average of 17,380 nuts per ha per year, in order to assess the adequacy of the current fertilizer recommendations to prevent a serious depletion of the nutrient reserves in the soil. 


\section{MATERIALS AND METHODS}

A block of ten coconut palms were selected from a $S_{1}$ land (land suitability class-1; Madampe series soil) at Bandirippuwa Estate, Lunuwila for the trial. Each coconut palm in this block was treated with $800 \mathrm{~g}$ urea, $600 \mathrm{~g}$ Eppawela Rock Phosphate, $1600 \mathrm{~g}$ Muriate of Potash and $1000 \mathrm{~g}$ Dolomite once a year. Weeding in the block was done twice a year with a mechanical slasher. Sampling was carried out for a two-year period from September 1998 to August 2000. Mature nuts, fallen nuts, fallen fronds and residues of inflorescence were collected each month. The fresh and dry weights of each plant component including husks, shell and kernel and the volume of nut water were determined.

Chemical analyses were performed on representative sub samples of each component of the main plant parts viz, perianth, husk, shell, kernel, nutwater, ekel, leaf blade, petiole of fronds; spike, spikelet, green spathe, dry spathe, male flowers and button nuts of the inflorescence. The sapples of the aforementioned components except nut- $\mathrm{w}_{\text {coter }}$ were dried at $70 \mathrm{C}$ for 3 days and powdered for chemical analysis. Nut-water samples were analyzed for $\mathrm{P}, \mathrm{K}, \mathrm{Ca}, \mathrm{Mg}, \mathrm{Na}, \mathrm{Fe}, \mathrm{Mn}, \mathrm{Cu}$ and $\mathrm{Zn}$ after evaporating to dryness followed by dry ashing. Nitrogen of each sample (including nutwater) was determined by the Kjeldhal method (Black, 1965). For analysis of $\mathrm{N}$ in nut-water, $100 \mathrm{ml}$ of sample was reduced to $3 \mathrm{ml}$ by evaporation. $\mathrm{P}$, $\mathrm{K}, \mathrm{Ca}, \mathrm{Mg}, \mathrm{Na}, \mathrm{Fe}, \mathrm{Mn}, \mathrm{Cu}$ and $\mathrm{Zn}$ were determined by digesting plant samples in 4: $1 \mathrm{HNO}_{3} / \mathrm{HClO}_{4}$ mixture (Mannual of analytical methods, 2000) followed by analysis using Auto Analyzer / Atomic Absorption Spectrophotometer. Nut-water and kernel analyses were performed on solutions prepared from plant samples ashed at $450^{\circ} \mathrm{C}$. Boron was determined by colorimetry with azomethine- $\mathrm{H}$ reagent.

Two years after commencement of the experiment, soil samples were collected from the manure circle of each palm and the centre of the coconut squares at $0-15 \mathrm{~cm}$ and $15-100 \mathrm{~cm}$ depths for determination of available exchangeable nutrients in the soil. Air-dried, $2 \mathrm{~mm}$ sieved samples were used for analysis. Total nitrogen of the soil samples was determined by the Kjeldhal digestion method. Available $\mathrm{P}$ content in the soil was determined by $2.5 \%$ HAc method (Anon, 1985), exchangeable bases ( $\mathrm{Na}, \mathrm{K}, \mathrm{Ca}$ and $\mathrm{Mg}$ ) by $1 \mathrm{M}$ ammonium acetate method (Thomas, 1982) and the available micronutrients of soil ( $\mathrm{Fe}, \mathrm{Mn}, \mathrm{Cu}$ and $\mathrm{Zn}$ ) by $0.005 \mathrm{M}$ DTPA-TEA extraction (Lindsay and Norvell, 1978).

The annual depletion of a nutrient from the soil in a hectare (a) was estimated by the equation $a=b+c-d$ 
Where, $\quad b=$ quantity of available or exchangeable nutrient in the soil per hectare up to $1 \mathrm{~m}$ depth,

$c=$ amount of the nutrient added with recommended fertilizer application and

$d=$ annual nutrient removal by the coconut palms in ha/yr

The time in the number of years taken for complete consumption of available nutrient reserves in the soil ( $t)$ was calculated by the formula $t=$ $b /(d-c)$

In this study, the depth of $1 \mathrm{~m}$ was considered as the effective rooting depth selected as only few roots were found below that level. In the case of nitrogen, the total nutrient content of the soil was considered instead of the available quantity because the quantity of available nitrogen is subjected to rapid changes with temperature, aeration, microbial population and moisture status.

Table 1. Weight of the dry matter of different components produced in a year

\begin{tabular}{|l|c|c|c|c|}
\hline $\begin{array}{l}\text { Plant } \\
\text { component }\end{array}$ & $\begin{array}{c}1998-1999 \\
\mathrm{~kg} / \mathrm{ha}\end{array}$ & $\begin{array}{c}1999-2000 \\
\mathrm{~kg} / \mathrm{ha}\end{array}$ & $\begin{array}{c}\text { Mean } \\
\mathrm{kg} / \mathrm{ha}\end{array}$ & $\begin{array}{c}\text { Percentage } \\
\text { of the total }\end{array}$ \\
\hline Nut & 18486.00 & 15913.76 & 17199.88 & 59.52 \\
Fallen fronds & 6964.64 & 8064.32 & 7514.48 & 26.00 \\
Inflorescence & 4108.00 & 4261.26 & 4184.63 & 14.48 \\
\hline Total & 29558.64 & 28239.34 & 28898.99 & 100.00 \\
\hline
\end{tabular}

Table 1 shows that the nut weight contributes almost $60 \%$ to the total dry matter production of the coconut palm whereas the weight of fronds contributes to $26 \%$. If the nuts and fronds are totally removed from the field, about $86 \%$ of the dry matter produced by the palm is taken away from the field along with the nutrients.

Table 2. Macronutrients removed from the field (kg/ha/yr) by different components of the nut

\begin{tabular}{|l|c|r|r|r|r|r|}
\hline $\begin{array}{l}\text { Component } \\
\text { of the nut }\end{array}$ & $\mathrm{N}$ & $\mathrm{P}$ & $\mathrm{K}$ & $\mathrm{Na}$ & $\mathrm{Ca}$ & $\mathrm{Mg}$ \\
\hline Nut water & 0.73 & 0.3 & 7.59 & 0.26 & 0.39 & 0.28 \\
Shell & 4.21 & 0.28 & 7.16 & 0.43 & 0.56 & 0.46 \\
Kernel & 46.07 & 6.38 & 24.25 & 0.32 & 1.02 & 3.67 \\
Husk & 24.52 & 2.67 & 146.56 & 11.03 & 4.30 & 5.72 \\
\hline Total & 75.53 & 9.63 & 185.56 & 12.04 & 6.27 & 10.13 \\
\hline
\end{tabular}


It is evident from Table 2 that nuts remove much larger quantities of potassium and nitrogen than other macronutrients, and that different parts of the nut remove different quantities of macronutrients. The data showed that $146.56 \mathrm{~kg}$ of $\mathrm{K}$ per ha was removed by the husk whereas only $39 \mathrm{~kg}$ of $\mathrm{K}$ per ha was removed by all the other components of the nut. In contrast, $46.07 \mathrm{~kg}$ of $\mathrm{N}$ per ha was removed by the kernel whereas only $29.47 \mathrm{~kg}$ of $\mathrm{N}$ per ha was removed by all the other parts. The $\mathrm{K}$ removal by the nut water and the shell were 7.59 and $7.16 \mathrm{~kg} / \mathrm{ha}$ respectively which are quite high compared to the other elements.

Table 3. Macronutrients removed from the field $(\mathrm{kg} / \mathrm{ha} / \mathrm{yr})$ by parts of fallen fronds and inflorescences

\begin{tabular}{|l|c|c|c|c|c|c|}
\hline $\begin{array}{l}\text { Parts of the } \\
\text { frond }\end{array}$ & $\mathbf{N}$ & $\mathbf{P}$ & $\mathbf{K}$ & $\mathbf{N a}$ & $\mathbf{C a}$ & $\mathbf{M g}$ \\
\hline Leaf blade & 21.38 & 1.19 & 13.40 & 5.98 & 10.51 & 4.71 \\
Petiole & 8.99 & 1.06 & 26.49 & 31.89 & 15.54 & 12.59 \\
Ekel & 3.01 & 0.21 & 3.72 & 2.66 & 4.61 & 3.01 \\
Inflorescence & 7.88 & 1.93 & 16.26 & 3.22 & 3.54 & 3.22 \\
\hline Total & 41.26 & 4.39 & 59.87 & 43.75 & 34.20 & 23.53 \\
\hline
\end{tabular}

The $\mathrm{Na}, \mathrm{K}, \mathrm{Ca}$ and $\mathrm{Mg}$ contents in the petiole were higher than that in the leaf blade and ekel. In contrast, the leaf blade removed a high proportion of $\mathrm{N}$ compared to the other parts of the frond. It is noteworthy that the petiole removes more sodium than potassium (Table 3 ) and the total quantity of sodium removed by fronds and inflorescence becomes second only to that of potassium. The possible role of $\mathrm{Na}$ in those plant parts merits investigation.

Table 4. Macronutrients removed from the field ( $\mathrm{kg} / \mathrm{ha} / \mathrm{yr})$ by nuts, fallen fronds and inflorescences of palms yielding 17,380 nuts/ha/yr

\begin{tabular}{|l|c|c|r|r|r|r|}
\hline $\begin{array}{l}\text { Parts of the } \\
\text { palm }\end{array}$ & $\mathbf{N}$ & $\mathbf{P}$ & $\mathbf{K}$ & $\mathbf{N a}$ & $\mathbf{C a}$ & $\mathbf{M g}$ \\
\hline Nuts & 75.53 & 9.63 & 185.56 & 12.04 & 6.27 & 10.13 \\
Fronds & 33.38 & 2.46 & 43.61 & 40.53 & 30.66 & 20.31 \\
Inflorescence & 7.88 & 1.93 & 16.26 & 3.22 & 3.54 & 3.22 \\
\hline Total & 116.79 & 14.02 & 245.43 & 55.79 & 40.47 & 33.66 \\
\hline
\end{tabular}


According to Table 4, potassium was removed in much larger quantities by the palm than the other nutrients, amounting to $245.43 \mathrm{~kg} / \mathrm{ha} / \mathrm{yr}$ which was $0.85 \%$ of the total dry matter. The next highest removal was of nitrogen amounting to $116.79 \mathrm{~kg} / \mathrm{ha} / \mathrm{yr}$ which was $0.40 \%$ of the total dry matter. Other macro nutrient removals in descending order were $\mathrm{Na}, \mathrm{Ca}, \mathrm{Mg}$ and $\mathrm{P}$ amounting to $0.19 \%, 0.14 \%, 0.12 \%$ and $0.05 \%$ of the total dry matter respectively. The total quantities of $\mathrm{N}$ and $\mathrm{K}$ removed by fronds were much lower than by nuts ( Table 4). In the case of $N$, the above difference was directly related to the weights of each component, as the $\mathrm{N}$ concentration in both components was $0.44 \%$. With $\mathrm{K}$, both lower weight and lower $\mathrm{K}$ concentration of the fronds $(0.58 \%$ in fronds and $1.08 \%$ in nuts) accounted for the difference. However, the quantities of sodium, calcium and magnesium removed by fronds was higher than by nuts.

The inflorescence parts contained quite a low quantity of nutrients compared to the fronds and nuts (Table 4). Nevertheless, they remove higher quantities of potassium and nitrogen compared to other nutrients. The quantities of $N, P, K, C a$ and $\mathrm{Mg}$ removed from the site via the palm components, the reserves of available macronutrients in the soil up to $1 \mathrm{~m}$ depth at the experimental site and the input of $\mathrm{N}, \mathrm{P}, \mathrm{K}, \mathrm{Ca}$ and $\mathrm{Mg}$ by the application of recommended coconut fertilizers are presented. in Table 5.

Table.5. Quantities of macronutrients (i) loss from the site via removal of nuts and other palm components, (ii) as soil reserves in "available" form and (iii) supplied by fertilizer inputs

\begin{tabular}{|c|c|c|c|c|c|}
\hline & $\mathbf{N}$ & $\mathbf{P}$ & K & $\mathrm{Ca}$ & $\mathbf{M g}$ \\
\hline $\begin{array}{l}\text { Nutrient removal } \\
\text { by nuts, fronds } \\
\text { and residues of } \\
\text { inflorescence of } \\
\text { coconut palms }\end{array}$ & $\begin{array}{c}\text { (kg/ha/yr) } \\
116.79\end{array}$ & $\begin{array}{c}\text { (kg/ha/yr) } \\
14.02\end{array}$ & $\begin{array}{c}\text { (kg/ha/yr) } \\
245.43\end{array}$ & $\begin{array}{c}\text { (kg/ha/yr) } \\
40.47\end{array}$ & $\begin{array}{c}(\mathrm{kg} / \mathrm{ha} / \mathrm{yr}) \\
33.66\end{array}$ \\
\hline $\begin{array}{l}\text { Nutrient content of } \\
\text { the soil in } \\
\text { experimental site } \\
\text { (up to } 1 \mathrm{~m} \text { depth) }\end{array}$ & $\begin{array}{l}\text { (kg/ha) } \\
9527^{d}\end{array}$ & $\begin{array}{c}\text { (kg/ha) } \\
320^{\circ}\end{array}$ & $\begin{array}{c}\text { (kg/ha) } \\
363^{\prime}\end{array}$ & $\begin{array}{c}\text { (kg/ha) } \\
883^{f}\end{array}$ & $\begin{array}{c}\text { (kg/ha) } \\
143^{f}\end{array}$ \\
\hline $\begin{array}{l}\text { Nutrient supplied } \\
\text { by application of } \\
4.5 \mathrm{~kg} \text { APM and } \\
1.5 \mathrm{~kg} \text { dolomite }\end{array}$ & $\begin{array}{c}\text { (kg/ha/yr) } \\
87.21\end{array}$ & $\begin{array}{c}\text { (kg/ha/yr) } \\
17.07\end{array}$ & $\begin{array}{c}\text { (kg/ha/yr) } \\
188.9\end{array}$ & $\begin{array}{c}\text { (kg/ha/yr) } \\
104.8\end{array}$ & $\begin{array}{c}(\mathrm{kg} / \mathrm{ha} / \mathrm{yr}) \\
28.59\end{array}$ \\
\hline
\end{tabular}


a Nutrient removal by nuts, fronds and residues of inflorescence of the coconut palms were calculated per hectare (158 palms) in a year. Average of two years removal data were used.

${ }^{b}$ Nutrient content of the soil was calculated by summing up the quantities of available nutrients in the manure circle and the rest of the area together up to a $1 \mathrm{~m}$ of depth.

c Quantity of nutrients supplied by application of $4.5 \mathrm{~kg} \mathrm{APM}$ and $1.5 \mathrm{~kg}$ dolomite per palm per year were converted to the rate of ha. per year (158 palms/ha).

d It was assumed that $1-2 \%$ the total $\mathrm{N}$ is in the available form

- $2.5 \%$ Acetic acid soluble phosphorus fraction

Exchangeable bases

Potassium input by the application of $4.5 \mathrm{~kg}$ of APM was about $75 \%$ of the potassium removal. Hence, high yielding coconut plantations would rapidly deplete exchangeable potassium of the soil, if the harvested nuts and fallen plant components are all removed from the plantation. At a production rate of 17,380 nuts/ha/yr, despite the recommended fertilizer application $(4.5 \mathrm{~kg}$ APM), the depletion rate of exchangeable potassium of the soil would be $56.53 \mathrm{~kg} / \mathrm{ha} / \mathrm{yr}$. The exchangeable $K$ pool in the soil is generally replenished by the non-exchangeable pool in the soil. Hence, it is necessary to quantify the non- exchangeable $K$ pool and determine the rate of replenishment of $\mathrm{K}$ in coconut growing soils.

It is assumed that $1-2 \%$ of the total nitrogen in a soil is available in inorganic form for plant uptake (Brady, 1990). Based on the above assumption, it can be considered that the total nitrogen quantity in the soil together with annual input by fertilizer is adequate to compensate for the removal by the palm provided the present level of total $N$ could be maintained.

The soil reserves of available phosphorus would not be depleted because the depletion is smaller than the input. As magnesium removal slightly exceeds the input by annual dolomite application, depletion of exchangeable magnesium reserves would occur in the long run. Calcium input by both rock phosphate and dolomite exceeds the uptake by the palm and therefore the reserves would be sustained.

The deficit between $\mathrm{K}$ loss from the field and the fertilizer input is 56.53 $\mathrm{kg} / \mathrm{ha} / \mathrm{yr}$. However, the fallen fronds in a year contain $43.61 \mathrm{~kg}$ of $\mathrm{K} / \mathrm{ha}$, $33.38 \mathrm{~kg}$ of $\mathrm{N} / \mathrm{ha}$ and $20.31 \mathrm{~kg}$ of $\mathrm{Mg} / \mathrm{ha}$. If all fallen fronds are applied as mulch to the manure circles and these nutrients are recycled to the soil, the rate of depletion of nutrients will be decreased considerably. 
It is important to note that the coconut husks produced in a year contained $146.56 \mathrm{~kg}$ of potassium per hectare (Table 2) which was $59.71 \%$ of the total potassium removal. Thus, a large fraction $(77.48 \%)$ of the potassium removed can be returned to the soil if both husks and fronds are incorporated into the soil. It helps saving on inorganic potassium fertilizer required to compensate for the depletion. It is important to note that potassium input to soil at the recommended rate of both fertilizer and a mulch with all the fallen coconut fronds would be $232.51 \mathrm{~kg} / \mathrm{ha} / \mathrm{yr}$, which is still less than the rate of depletion by the palm. The rate of depletion can be exceeded if all the husks are incorporated to the soil in addition to application of the fertilizer and the mulch. However, such practices are not possible because of the industrial value of the husk. Application of mulch also would serve to replenish a major part of sodium removed, since fallen fronds contained $72.6 \%$ of the total removal.

Furthermore, potassium in the chemical fertilizers, when applied in high quantities tends to leach or interact with other nutrients such as $\mathrm{Ca}$ and $\mathrm{Mg}$ in the soil causing imbalances in soil-plant relationship. Therefore, application of high quantities of chemical fertilizer once a year may not be an appropriate practice to avoid depletion of soil nutrients. Application of split inorganic fertilizer dozes also presents problems such as high labour cost, lack of labour and uncertainty of weather patterns. Thus, the proper approach is to balance the plant nutrients in coconut plantations by incorporating organic residues of the palm itself to the soil and apply inorganic fertilizers only to make up for the difference between the input and the total removal.

Table 6. Micronutrients removed from the field $(\mathrm{kg} / \mathrm{ha} / \mathrm{yr})$ by nuts, fallen fronds and inflorescences of palms yielding 17,380 nuts/ha/yr

\begin{tabular}{|l|c|c|c|c|c|}
\hline $\begin{array}{l}\text { Parts of the } \\
\text { palm }\end{array}$ & Fe & Mn & Cu & Zn & B \\
\hline Nuts & 0.47 & 0.10 & 0.11 & 0.16 & 0.15 \\
Fronds & 0.61 & 0.50 & 0.01 & 0.15 & 0.09 \\
Inflorescence & 0.06 & 0.03 & 0.01 & 0.13 & 0.02 \\
\hline Total & 1.14 & 0.63 & 0.13 & 0.44 & 0.26 \\
\hline
\end{tabular}

With regard to the removal of micronutrients, $\mathrm{Cu}$ was the lowest at 0.13 $\mathrm{kg} / \mathrm{ha} / \mathrm{yr}$. Harvested nuts removed most of the $\mathrm{Cu}$, whereas fronds removed much of the Mn. Removal by both fronds and nuts, Fe was relatively high. Nuts, fronds and inflorescence removed $Z n$ equally but nuts removed a higher quantity of B than other parts. In terms of total removal, Fe was the highest followed by $\mathrm{Mn}, \mathrm{Zn}, \mathrm{B}$ and $\mathrm{Cu}$ respectively (Table 6). 
Table 7. Quantities of micronutrients (i) lost from the site via removal of nuts and other plant components, (ii) as soil reserves in "available form" and (iii) supplied by fertilizer inputs

\begin{tabular}{|c|c|c|c|c|c|}
\hline & $\mathrm{Fe}$ & $\mathbf{M n}$ & $\mathrm{Cu}$ & $\mathrm{Zn}$ & B \\
\hline $\begin{array}{l}\text { Nutrient removal by } \\
\text { nuts, fronds and } \\
\text { residues of } \\
\text { inflorescence of } \\
\text { coconut palms }\end{array}$ & $\begin{array}{c}\text { (kg/ha/yr) } \\
1.14\end{array}$ & $\begin{array}{c}\text { (kg/ha/yr) } \\
0.63\end{array}$ & $\begin{array}{c}\text { (kg/ha/yr) } \\
0.13\end{array}$ & $\begin{array}{c}\text { (kg/ha/yr) } \\
0.44\end{array}$ & $\begin{array}{c}\text { (kg/ha/yr) } \\
0.26\end{array}$ \\
\hline $\begin{array}{l}\text { Nutrient status of the } \\
\text { soil in experimental } \\
\text { site } \\
\text { (up to } 1 \mathrm{~m} \text { depth) }\end{array}$ & $\begin{array}{l}\text { (kg/ha) } \\
324.50^{d}\end{array}$ & $\begin{array}{l}\text { (kg/ha) } \\
11.73^{d}\end{array}$ & $\begin{array}{c}\text { (kg/ha) } \\
7.48^{d}\end{array}$ & $\begin{array}{c}\text { (kg/ha) } \\
6.91^{\mathrm{d}}\end{array}$ & Nd \\
\hline $\begin{array}{l}\text { Nutrient supplied by } \\
\text { application of } 4.5 \mathrm{~kg} \\
\text { APM and } 1.5 \mathrm{~kg} \\
\text { dolomite }\end{array}$ & $\begin{array}{c}\text { (kg/ha/yr) } \\
2.82\end{array}$ & $\begin{array}{c}\text { (kg/ha/yr) } \\
0.36\end{array}$ & $\begin{array}{c}(\mathrm{kg} / \mathrm{ha} / \mathrm{yr}) \\
0.02\end{array}$ & $\begin{array}{c}(\mathrm{kg} / \mathrm{ha} / \mathrm{yr}) \\
0.05\end{array}$ & $\mathrm{Nd}$ \\
\hline
\end{tabular}

a Nutrient removal by nuts, fronds and residues of inflorescence of the coconut palms were calculated per hectare (158 palms) in a year. Average of two years removal data were used.

b nutrient status of the soil was calculated by summing up the quantity of available nutrients in the rest of the area.

c quantity of nutrients supplied by application of $4.5 \mathrm{~kg} \mathrm{APM}$ and $1.5 \mathrm{~kg}$ dolomite per palm per year were converted to the rate of hectare per year (158 palms/ha).

dAvailable micronutrients

Nd- Not determined

Soil reserves of available $\mathrm{Fe}$ were much greater than the quantity of $\mathrm{Fe}$ annually removed by the palm (Table 7). The reserves of available $\mathrm{Fe}$ in the soil may be sufficient for about 300 years at the present depletion rate in the experimental site. But the ratios of removal to soil reserves for $\mathrm{Mn}, \mathrm{Cu}$ and $\mathrm{Zn}$ were $18.62,57.54$ and 15.71 respectively.

Micronutrients are present in APM fertilizers as impurities. With APM application, the input of $\mathrm{Fe}$ is sufficient to make up for the removal and input of $\mathrm{Mn}$ would compensate for one third of the removal. Input of $\mathrm{Cu}$ and $\mathrm{Zn}$ is very small compared to the removal. Considerable amount of micronutrient removed by coconut palm could also be returned to the soil by using fronds, husks and inflorescence parts as mulch or manure (Table 6). But still there is a deficit between the removal of $\mathrm{Cu}, \mathrm{Zn}$ and $\mathrm{B}$ from the field and the input by the mulch and impurities in the fertilizer. Therefore, application of a 
maintenace doze of $\mathrm{Cu}, \mathrm{Zn}$ and $\mathrm{B}$ to high yielding palms will be useful to conserve the reserves in the soil.

\section{CONCLUSION}

There is a considerable deficit between the loss of nitrogen and potassium from the field and the input of the same nutrienrs with $4.5 \mathrm{~kg}$ of APM per palm per year when the coconut palms yield at 17,380 nuts/ha/yr. Phosphorus and calcium loss from the field due to high yielding palm is compensated by the input of the same nutrient by fertilizer. There is a slight deficit between the loss of magnesium from the field and the input with 1.5 $\mathrm{kg}$ dolomite per palm per year. However the aforementioned gaps between loss and input of nutrients except potassium can be filled by applying its own fallen coconut fronds as a mulch to the palm. In the case of potassium, coconut husks also have to be used as a potassium source in addition to the recommended chemical fertilizer dosage and the mulch comprising coconut fronds. However, it is more logical to apply potassium fertilizer to bridge the gap, than use coconut husks, because the latter is used for industrial purposes.

The reserve of available $\mathrm{Fe}$ in Madampe series soil was very high compared to removals by the palm and therefore application of fertilizer containing $\mathrm{Fe}$ would not be necessary: In the case of $\mathrm{Cu}, \mathrm{Zn}$ and $\mathrm{B}$, the gaps between the inputs as the mulch and fertilizer residues and the removal from the field appears to be small compared to the soil reserves but there will be a longterm depletion. However, the loss of $\mathrm{Mn}$ from the field is compensated by the input of fertilizer residue and the mulch. Therefore, application of $\mathrm{Cu}$, $\mathrm{Zn}$ and $\mathrm{B}$ fertilizers to maintain the soil reserves of the nutrients in fields containing high yielding coconut palms is recommended. 


\section{REFERENCES}

Anon, (1985). Advisory soil analysis and interpretations bulletin 1. Macaulay Institute for Soil Research and Scottish Agricultural Colleges Liaison group.4

Black, C.A. (1965). Methods of soil analysis. Part 2. $2^{\text {nd }}$ edition, American Society of Agronomy Monography 9.

Brady, N.C. (1990). The nature and properties of soils, $10^{\text {th }}$ edition, McMillan Publishing Company, New York

Jayasekara, K.S. Jayasekara, C. and Periyathamby, S. (1991). Report of the Soils and Plant Nutrient Division, Annual Report of Coconut Research Institute, Lunuwila, Sri Lanka

Jeganathan, M. Appuhamy, P.A. D.G.A. Mendis, B.J.A.F and George, G.D. (1977). Study on the annual exhaust of soil nutrients by the Typica $x$ Pumila hybrid palm, Proceedings of the Sri Lanka Association for the Advancement of Science, 32 (1) 43.

Lindsay, W.L. and Norvell, W.A. (1978). Development of a DTPA Soil Test for Zinc, Iron, Manganese and Copper, Soil. Sci. Soc. Am. J., 42: 421 - 428.

Mahindapala, R and Pinto, J.L.J.G. (1991). Coconut Cultivation, Coconut Research Institute, Lunuwila, Sri Lanka. 162.

Mannual of analytical Methods (2000). Soil and Plant Nutrition Division, Coconut Research Institute, Lunuwila, Sri Lanka

Ohler, J. G. (1984). Coconut tree of life., Food and agriculture organization of the United Nations, Rome.

Somasiri, L. L. W. Nadarajah, N. Amarasinghe, L. and Gunathilake, H.A.J. (1994). Land Suitability assessment of coconut growing area in the coconut triangle. Occasional Publication Series No.3, Coconut Research Institute, Lunuwila, Sri Lanka.

Somasiri, L. L. W. Wijebandara, D.M.D.I., Sabaratnam, S. Panditharatna, B.D.P. and Perera, U.S.S. (2000). Removal of plant nutrients of soils by nuts of coconut palms Proceedings of the Sri Lanka Association for the Advancement of Science, 56 (1) 77.

Somasiri, L.L. W. Wijebandara, D.M.D.I. Panditharatna, B.D.P. Sabaratnam, S. Kurundukumbura, C.P.A. and Pathirana, K.P.A. (2001). Study on nutrient removal by Typica $\times$ Typica coconut palms in high potential lands. Proceedings of the Sri Lanka Association for the Advancement of Science, 57 (1) 40.

Thomas, G.W. (1982). Exchangeable cations, In: Page, A. L., Miller, R. H. and Keeney, D.R., Methods of soil analysis, Part 2 - Chemical and Microbiological properties, Agronomy No. 9, Madison, Wisconsin, U.S.A. 159 - 164. 